\title{
The Indonesian Experience in Sharia Bank's Financial Performance Based on Index of Islamic Social Reporting and Sharia Supervisory Board
}

\author{
Nur Fitriana Hamsyi ${ }^{1}$ \\ \{nur.fitrianah@ekonomi.untan.ac.id ${ }^{1}$ \} \\ Universitas Tanjungpura, J1. Prof. Dr. H. Hadari Nawawi, Pontianak, Kalimantan Barat, Indonesia ${ }^{1}$
}

\begin{abstract}
Corporate Social Responsibility (CSR) disclosure in conventional banks is more excellent than in Islamic banks. The higher the CSR disclosure component reflected in the Index of Islamic Social Reporting (IISR), the more the company cares about the surroundings. This study examines IISR on financial performance. Not only that, but this study also uses the number of meetings (NB) and educational background (EB) as proxies for the sharia supervisory board (SSB) because testing this variable is still limited. This study used content analysis of annual reports of 10 sharia banks in Indonesia. Panel data regression was used for the period 2014-2018. The results showed that the IISR and EB variables did not influence to ROA. Meanwhile, the variable number of meetings has a negative effect on the amount of ROA.
\end{abstract}

Keywords: Index of Islamic social reporting, sharia supervisory board, return on assets, financial performance, sharia bank.

\section{Introduction}

Several parties are still debating the implementation of Corporate Social Responsibility (CSR). On the one hand, companies are required to be profit-oriented, but on the other hand, the company must spend several costs to carry out CSR activities. The company has broader accountability, namely how to have social benefits felt by the environment and society. It is essential to maintain the company's reputation, maintain corporate relations with the environment and community, and add more value to stakeholders'eyes. Not only limited in carrying out, but companies must also disclose CSR activities carried out in their annual report so that the public can find out [1]. Islamic banking is included in the company's part that must contribute to the implementation of CSR. This thing is in line with Islamic values, where Islam places great emphasis on social and environmental concerns, individual and entity ethics, and good governance $[2,3]$.

A benchmark for Islamic social reporting (ISR) is used to measure social responsibility implementation carried out by sharia banking, containing CSR standard items [4]. This index is determined based on the Accounting and Auditing Organization for Islamic Financial Institutions (AAOIFI), further developed by researchers related to standard CSR disclosure items. ISR disclosures in Islamic commercial banks in Indonesia are still considered low, and the average achievement is below $50 \%[5,6,7]$. It is a concern for Islamic banks to be more transparent and accountable in disclosing CSR information, considering that Islamic banks have 
more substantial social aspects than conventional banks. With the Index of IISR, it can be seen how much social performance is owned by Islamic banks [8, 9]. Investors will be more interested and feel safe to invest in companies responsible for the social and environmental dimensions reflected in the high IISR.

The existence of a sharia supervisory board (SSB) can improve the supervision and disclosure of information related to CSR in Islamic banks. The effectiveness of supervision carried out by SSB can be seen from the number of meetings. Educational background can affect the quality of SSB. The more SSB knows the field of Islamic economics and banking, the more in the study and supervision carried out. The deeper the educational experience possessed, the more competent the SSB is to effectively carry out its duties and functions. With a high IISR and the influential role of the SSB expected to improve Islamic banking financial performance. The studies and literature discussing the educational background and the number of SSB meetings are still limited. Therefore, this study intends to determine whether the level of the index of ISR disclosed by Islamic banks and the existence of a sharia supervisory board will affect the financial performance of sharia banks in Indonesia.

\section{Literature Review}

Three pillars measure the value of a company's success: economic, environmental, and social. These three pillars are illustrated in the Tripple Bottom Line (TBL) concept introduced by John Elkington, which later became the basis for implementing CSR. TBL's idea consists of $3 \mathrm{P}$, namely, Profit, People, and Planet $[10,11]$. TBL makes the company concerned with the interests of shareholders and covers the interests of stakeholders. CSR dates back to the 19th century, and recently, its development has accelerated so that it has made world attention increasingly towards CSR [12]. CSR is a continuing commitment by companies to ethical behavior that integrates social and environmental concerns in their business operations to contribute to economic development to improve employees' welfare and their families, local communities, and the wider community $[13,14]$.

Islam regulates human relations with God and humans relations with humans and the relationship between humans and their environment. It is based on Islamic banking, which bases its activities on Islamic principles and values to pay attention to environmental dimensions. The aim of Islamic social reporting (ISR) within the framework of Islamic perspectives is to show accountability to God and society while increasing business activities [4]. The financial statements must disclose all of their operations to achieve this goal so that sharia provisions can ensure everything. Islamic social reporting is a standard for measuring social performance reporting from companies based on sharia-based activities. There are six themes for disclosure in the index of Islamic social reporting (IISR): finance and investment, product or services, employee, society, environment, and corporate governance [15]. As a form of social responsibility reporting framework, IISR presents spiritual values.

To monitor and see the extent to which Islamic banks' disclosures have complied with Islamic values and are by established standards, the role of the sharia supervisory board (SSB) is very much needed. The SSB consists of shari'a experts who know Islamic sciences and Islamic financial issues from Islamic jurists and comparative laws [16]. The proxies used in this SSB are the number of meetings and the educational background. EB is an essential factor that must 
be considered. SSB that knows sharia, muamalah, and the banking economy will be more indepth in examining the problems faced by Islamic banks in Islamic law. Besides, the high frequency of SSB meetings can produce appropriate supervisory policies and monitor the risks faced by Islamic banking so that banks are more careful in carrying out activities that are not profitable and outside of Islamic principles. With a high IISR, it indicates intensive supervision from SSB on CSR disclosure.

The more in-depth CSR exposure by Islamic banks will increase investors' attractiveness and security to invest in Islamic banks that have strong environmental and social concerns. It is expected to improve the financial performance of Islamic banks, one of which is the ratio of return on assets (ROA). This financial ratio measures management success in generating profit returns by using the company [17]. The higher the ROA produced by Islamic banks, the better its financial performance from the use of its assets.

In [18-22], the effect of CSR disclosure on ROA was tested, and the results showed positive influences between the two variables. On the contrary, banks carrying out many CSR activities showed low profitability, although statistically, the results were not significant. The higher the CSR score, the lower the ROA [23]. Research on SSB has been carried out by [24], which proves the influence of SSB on Islamic banks'performance. The findings of $[25,26]$ reveal a positive relationship between a board of director meetings and corporate financial performance. However, [27] argued that a large number of meetings could increase operational and agency costs to decrease the ROA value. The educational qualification can help attract potential investors, increasing Islamic banks' productivity and performance [28]. Meanwhile, [29] stated that SSB expertise has no direct effect on ROA. The conceptual framework of this study can be seen in Figure 1.

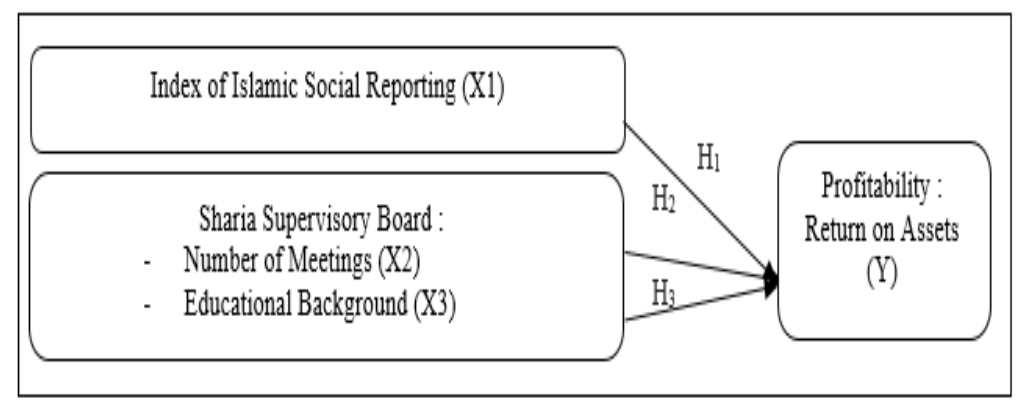

Fig. 1. Conceptual Framework

The hypothesis in this study can be formulated as follows:

H1 IISR positively effects on ROA of Islamic banks.

$\mathbf{H}_{2}$ Number of meetings positively effect on ROA of Islamic banks.

$\mathrm{H}_{3}$ Educational background positively effects on ROA of Islamic banks. 


\section{Methodology and Data Analysis}

Quantitative research is used to test this hypothesis, with secondary data obtained from each Sharia commercial bank's annual report in Indonesia. This study analyses the Islamic social reporting index and sharia supervisory board's effect on sharia bank's financial performance in the listed Financial Services Authority (OJK) in Indonesia for 2014-2018. From the total population in that period, there were 11 Islamic banks. The sample obtained is 10 Islamic banks with the criteria for issuing complete annual reports, and the ROA obtained does not exceed $15 \%$. The independent variable employed in this study is the IISR with disclosures of 48 items, and SSB with a proxy for the number of meetings and educational background. Meanwhile, the dependent variable is a financial performance with ROA proxy.

\section{Research Result and Discussion}

Before choosing a panel data regression model, the data were analyzed by performing three regression models. As a first step, data analysis was carried out by testing the common effect model (CEM), as shown in Table 1 .

Table 1. Regression Result of Common Effect Model Test

\begin{tabular}{ccccc}
\hline Variable & Coefficient & Std. Error & t-Statistic & Prob \\
\hline C & 1.804909 & 4.468864 & 0.403885 & 0.6882 \\
IISR & 0.554414 & 5.797682 & 0.095627 & 0.9242 \\
NM & -0.149920 & 0.073399 & -2.042538 & 0.0469 \\
EB & -0.110943 & 0.875879 & -0.126664 & 0.8998 \\
\hline
\end{tabular}

Table 1 shows one variable with a t-test probability that looks significant with alpha $=5 \%$. The value of the number of meetings, namely 0.0469 , is smaller than $5 \%$. Next, the data is processed by the fixed effect model (FEM). The output result is that no one variable looks significant. The third is the random effect model (REM). From the output results from panel data regression with the REM, there is one variable with individual tests ( $\mathrm{t}$-test probability) that looks significant with alpha $=5 \%$, NM $0.0435<0.05$. The next step is to select a panel data regression model. The Chow test determines the selection between the CEM or the FEM. The output results from this model in the following table:

Table 2. Result of the Chow Test

\begin{tabular}{cccc}
\hline Effects Test & Statistic & d.f. & Prob. \\
\hline Cross-section F & 1.590296 & $(9,37)$ & 0.1543 \\
Cross-section Chi-square & 16.350982 & 9 & 0.0599 \\
\hline
\end{tabular}

Table 2 reports that the $\mathrm{p}$-value obtained in the chi-square cross-section is $0.0599>\alpha=5 \%$, 
so $\mathrm{H}_{0}$ is accepted, which means that the CEM model is better used FEM. Then the next step is to use the Hausman Test. The probabilistic significance shows a value of 0.9911 , which means p-value $>0.05$. It is necessary to consider the Lagrange multiplier (LM) test. The output results from panel data regression with the LM test can be seen as follows:

Table 3. Result of Lagrange Multiplier

\begin{tabular}{cccc}
\hline & Cross-section & $\begin{array}{c}\text { Test Hypothesis } \\
\text { Time }\end{array}$ & Both \\
\hline Breusch-Pagan & 0.940714 & 0.101602 & 1.042317 \\
& $(0.3321)$ & $(0.7499)$ & $(0.3073)$ \\
\hline
\end{tabular}

Based on Table 3, the cross-section shows a value of 0.3321 and both 0.3073 . It means p-value $>0.05$. So that the decision taken from this LM model is to choose CEM as the best model. The regression equation obtained from the CEM shows in the form of:

$$
\text { ROA=1.804909+0.554414IISR-0.149920NM-0.110943EB. }
$$

Based on the regression test results in Table 1, the probability of the IISR is -0.9242 , which means IISR does not influence ROA. The existence of CSR disclosures does not determine the company's profit. In knowing 2017, BNI Syariah gets an IISR score higher than in 2017, and the resulting ROA is lower than in 2016. The high IISR score shows the broader disclosure made and the better the social performance of Islamic banks, but it does not impact increasing assets' profits. This thing is due to CSR carried out by Islamic banks not related to activities that generate profits, but rather lead to social events where the company must issue several costs from the allocating profit. This research is not in line with [15-19], who stated that IISR has a positive effect on ROA.

Conversely, for the variable sharia supervisory board, the number of meetings negatively affects ROA. The results obtained amounted to 0.0469 with a coefficient of -0.149920 . The more the number of meetings, the lower the ROA. The more frequent meetings, it does not guarantee the effectiveness of meetings to produce strategic decisions. Even it can cause inefficiency and ineffectiveness, which will reduce the company's ROA because it is related to the costs incurred in organizing the meeting. In [30] argued against replacing regular meetings with emergency meetings, such as discussing if a company is experiencing financial difficulties. The number of meetings that are too large could indicate a problem with the company. It will have an impact on the company's image and reduce stakeholder trust. There are still many SSB that do not attend the meeting, which can make the meeting's quality not optimal, so the meeting must be repeated. So, not all SSB members can give opinions to produce effective decisions, influencing decisions taken to increase Islamic banks' supervision and performance. This research is in line with research from [31] and contrary to research from $[22,23]$.

While the educational background does not affect ROA, as shown in Table 1, resulting in a negative coefficient of 0.110943 and a probability of 0.8998 . To become an SSB, someone must have an educational background in sharia muamalah and banking or finance in general. Educational background can affect a person's professionalism. However, it turns out that the 
results of the research prove that even though the SSB's background can meet the educational qualifications, it does not affect the ROA produced by the company. Higher education's background does not necessarily guarantee someone to make strategies and make the best decisions in solving problems in the company. This research is in line with [29]. On the contrary, it is not in line with the research [28].

\section{Conclusion}

The results of the analysis prove that the IISR variable does not effect on ROA. A high IISR score shows high social activity but is not related to profit-generating activities. Likewise, the number of meetings has a negative influence on ROA. The number of meetings cannot guarantee a good quality meeting, but rather by the essence of the matters discussed so that a large number of meeting frequency can reduce the ROA value. Likewise, with the number of meetings that many do not impact improving financial performance, the reduced number of members present will influence the decisions produced. In contrast, the educational background does not influence on ROA. For further research, it is expected to expand the study's object by comparing with other countries in CSR disclosure or disclosing the IISR in broader Islamic financial institutions, not only on Islamic banks.

\section{References}

[1] S. Leitoniene and A. Sapkauskiene, "Quality of Corporate Social Responsibility Information," Procedia - Soc. Behav. Sci., vol. 213, pp. 334-339, 2015, DOI: 10.1016/j.sbspro.2015.11.547.

[2] M. Asutay, "Islamic moral economy as the foundation of Islamic finance," Islamic Finance in Europe., pp. 55-68, 2013, DOI: 10.4337/9781781002513.00014.

[3] I. Siswanti, "The Influence of Financial Performance and Non-Financial Performance on Islamic Social Responsibility Disclosure : Evidence from Islamic Banks in Indonesia," Int. J. Account. Bus. Soc., vol. 26, no. 2, pp. 81-96, 2018.

[4] R. Haniffa, "Social Reporting Disclosure: An Islamic Perspective," Indones. Manag. Account. Res., vol. 1, no. 2, pp. 128-146, 2002.

[5] W. A. W. Abdullah, M. Percy, and J. Stewart, "Shari'ah disclosures in Malaysian and Indonesian Islamic banks: The Shari'ah governance system," J. Islam. Account. Bus. Res., vol. 4, no. 2, pp. 100-131, 2013, DOI: 10.1108/JIABR-10-2012-0063.

[6] S. Darmadi, "Corporate governance disclosure in the annual report: An exploratory study on Indonesian Islamic banks,” Humanomics, vol. 29, no. 1, pp. 4-23, 2013,

DOI: 10.1108/08288661311299295.

[7] T. B. Pepinsky, "Development, Social Change, and Islamic Finance," Contemp. Indones. Dev., vol. 14, pp. 157-167, 2013.

[8] A. M. Migdad, "CSR practices of Palestinian Islamic banks: contribution to socio-economic development," ISRA Int. J. Islam. Financ., vol. 9, no. 2, pp. 133-147, 2017, DOI: 10.1108/IJIF-062017-0001.

[9] M. H. Ullah and M. A. Rahman, "Corporate social responsibility reporting practices in banking companies in Bangladesh," J. Financ. Report. Account., vol. 13, no. 2, pp. 200-225, 2015, DOI: 10.1108/jfra-05-2013-0038.

[10] J. Hammer and G. Pivo, "The Triple Bottom Line and Sustainable Economic Development Theory and Practice," Econ. Dev. Q., vol. 31, no. 1, pp. 25-36, 2017.

[11] E. Lemus, "The Importance of CSR in Financial Reporting Standards," Type Double-Blind Peer Rev. Int. Res. J. Publ. Glob. Journals Inc, vol. 16, no. 2, 2016, [Online]. Available: https://globaljournals.org/GJMBR_Volume16/3-The-Importance-of-CSR.pdf. 
[12] A. Ahmadian and S. Khosrowpour, "Corporate Social Responsibility: Past, Present, And Success Strategy For The Future,” J. Serv. Sci., vol. 10, no. 1, pp. 1-12, 2017, DOI: 10.19030/jss.v10i1.10063. [13] Comisión Europea, Observatory of European SMEs European SMEs and Social and Environmental Responsibility, no. 4. 2002.

[14] R. Holme and P. Watt, "Corporate Social Responsibility: Making Good Business Sense," World Bus. Counc. Sustain. Dev., 2000, DOI: 10.1177/004051757504501107.

[15] R. Othman, A. M. Thani, and E. K. Ghani, "Determinants of Islamic Social Reporting Among Top Shariah-Approved Companies in Bursa Malaysia. Research Journal of International Studies," Res. J. Int. Stud., no. 12, pp. 4-20, 2009.

[16] Z. Ramly, Nurusysyifa, and Mohamad, "Sharia supervision board, board independence, risk committee and risk-taking of Islamic banks in Malaysia," International Journal of Economics and. Financial Issues, vol. 8, no. 4, pp. 290-300, 2018.

[17] Rosikah, D. K. Prananingrum, D. A. Muthalib, M. I. Azis, and M. Rohansyah, "Effects of Return on Asset, Return on Equity, Earning Per Share on Corporate Value," Int. J. Eng. Sci., vol. 7, no. 3 Ver.I, pp. 6-14, 2018, DOI: 10.9790/1813-0703010614.

[18] R. Othman and A. M. Thani, "Islamic Corporate Social Responsibility, Corporate Reputation and Performance,” Int. Sch. Sci. Res. Innov., vol. 6, no. 4, pp. 643-647, 2012.

[19] M. N. F. Herwanti, Titiek; Irwan, "Disclosure Level's Effect of Islamic Social Reporting on Company's Profitability and Zakat," vol. 6, no. 2, pp. 85-98, 2017.

[20] A. P. Mansaray, L. Yuanyuan, and S. Brima, "The Impact of Corporate Social Responsibility Disclosure on Financial Performance of Firms in Africa," International Journal of Economics and. Financial Issues, vol. 7, no. 5, pp. 137-146, 2017, [Online]. Available: https://ideas.repec.org/a/eco/journ1/2017-05-16.html.

[21] Ł. Matuszak and E. Różańska, "An examination of the relationship between CSR disclosure and financial performance: The case of Polish banks," J. Account. Manag. Inf. Syst., vol. 16, no. 4, pp. 522533, 2018, DOI: 10.24818/jamis.2017.04005.

[22] M. Rehan, M. I. Khan, and M. K. Khan, "Effect of Corporate Social Responsibility on Profitability of Banks," Eur. Acad. Res., vol. 6, no. 7, pp. 3763-3782, 2018.

[23] D. Taskin, "The Relationship between CSR and Banks' Financial Performance: Evidence from Turkey," J. Yaşar Univ., vol. 10, no. 39, p. 21, 2015, DOI: 10.19168/jyu.97694.

[24] N. M. Nomran, R. Haron, and R. Hassan, "Bank Performance and Shari'ah Supervisory Board Attributes of Islamic Banks : Does Bank Size Matter?,” J. Islam. Financ., vol. 6, no. Special Issue, pp. 174-187, 2018, DOI: 10.12816/0047348.

[25] S. C, Gavrea and R, "Corporate Governance and Firm Performance: The Romanian Case," Manag. Challenges Contemp. Soc., vol. 3, no. 1, pp. 179-185, 2012.

[26] A. Sahu, T. N, and Manna, "Impact of Board Composition and Board of Meeting on Firm's Performance; A Study of Selected Indian Companies," J. Manage., vol. 10, no. 2, 2013.

[27] B. J. Bushee, M. E. Carter, and J. Gerakos, "Institutional investor preferences for corporate governance mechanisms," J. Manag. Account. Res., vol. 26, no. 2, pp. 123-149, 2014.

[28] R. Grassa, Corporate governance and credit rating in Islamic banks: Does Shariah governance matter? vol. 20, no. 4. Springer US, 2016.

[29] H. Mukhibad and I. Anisykurlillah, "Evaluation Study: Does The Sharia Supervisory Board Have A Direct Effect on Profitability?," Muqtasid J. Ekon. dan Perbank. Syariah, vol. 11, no. 1, pp. 55-69, 2020, DOI: 10.18326/muqtasid.v11i1.55-69.

[30] C. G. Ntim, T. Soobaroyen, and M. J. Broad, "Governance structures, voluntary disclosures and public accountability: The case of UK higher education institutions," Accounting, Audit. Account. J., vol. 30, no. 1, pp. 65-118, 2017, DOI: 10.1108/AAAJ-10-2014-1842.

[31] J. Bushee, B., Carter, M., and Gerakos, "Institutional investor preferences for corporate governance mechanisms," J. Manag. Account. Res., vol. 3, no. 1, pp. 123-149, 2014. 